\title{
Metal(loid)s role in the pathogenesis of amyotrophic lateral sclerosis: Environmental, epidemiological, and genetic data
}

\author{
Marina Tesauro $^{\mathrm{a}, * *}$, Maurizio Bruschi ${ }^{\mathrm{b}, 1}$, Tommaso Filippini ${ }^{\mathrm{c}}$, Sandra D'Alfonso ${ }^{\mathrm{d}}$, Letizia Mazzini ${ }^{\mathrm{e}}$, \\ Lucia Corrado $^{\mathrm{d}}$, Michela Consonni ${ }^{\mathrm{a}}$, Marco Vinceti ${ }^{\mathrm{c}, \mathrm{g}}$, Paola Fusi ${ }^{\mathrm{f}, 2}$, Chiara Urani ${ }^{\mathrm{b}, 2, *}$ \\ a Department of Biomedical, Surgical and Dental Sciences, University of Milan, Via C. Pascal, 36, 20133, Milan, Italy \\ ${ }^{\mathrm{b}}$ Department of Earth and Environmental Sciences, University of Milano - Bicocca, Piazza della Scienza, 1, 20133, Milan, Italy

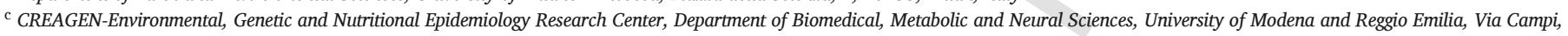 \\ 287, 41125, Modena, Italy \\ ${ }^{\mathrm{d}}$ Department of Health Sciences, CAAD, UPO University, Via Solaroli, 17, 28100, Novara, Italy \\ e ALS Centre Department of Neurology, Maggiore della Carità University Hospital, Corso Mazzini, 18, 28100, Novara, Italy \\ ${ }^{\mathrm{f}}$ Department of Biotechnology and Biosciences, University of Milano-Bicocca, Piazza della Scienza, 2, 20126, Milan, Italy \\ ${ }^{g}$ Department of Epidemiology, Boston University School of Public Health, Boston, 715 Albany Street, MA 02118, USA
}

\section{A R T I C L E I N F O}

Keywords

Amyotrophic lateral sclerosis metal(loid)s

Environmental matrices

Epidemiology

Gene mutations

\begin{abstract}
A B S T R A C T
Amyotrophic Lateral Sclerosis (ALS) is a progressive neurodegenerative disorder of the motor system. The etiology is still unknown and the pathogenesis remains unclear. ALS is familial in the $10 \%$ of cases with a Mendelian pattern of inheritance. In the remaining sporadic cases, a multifactorial origin is supposed in which several predisposing genes interact with environmental factors. The etiological role of environmental factors, such as pesticides, exposure to electromagnetic fields, and metals has been frequently investigated, with controversial findings. Studies in the past two decades have highlighted possible roles of metals, and ionic homeostasis dysregulation has been proposed as the main trigger to motor-neuron degeneration. This study aims at evaluating the possible role of environmental factors in etiopathogenesis of ALS, with a particular attention on metal contamination, focusing on the industrial Briga area in the province of Novara (Piedmont region, North Italy), characterized by: $i$ ) a higher incidence of sporadic ALS (sALS) in comparison with the entire province, and ii) the reported environmental pollution. Environmental data from surface, ground and discharge waters, and from soils were collected and specifically analyzed for metal content. Considering the significance of genetic mechanisms in ALS, a characterization for the main ALS genes has been performed to evaluate the genetic contribution for the sALS patients living in the area of study. The main findings of this study are the demonstration that in the Briga area the most common metal contaminants are $\mathrm{Cu}, \mathrm{Zn}, \mathrm{Cr}$, Ni (widely used in tip-plating processes), that are above law limits in surface waters, discharge waters, and soil. In addition, other metals and metalloids, such as $\mathrm{Cd}, \mathrm{Pb}$, $\mathrm{Mn}$, and As show a severe contamination in the same area. Results of genetic analyses show that sALS patients in the Briga area do not carry recurrent mutations or an excess of mutations in the four main ALS causative genes (SOD1, TARDBP, FUS, C9ORF72) and for ATXN2 CAG repeat locus. This study supports the hypothesis that the higher incidence of sALS in Briga area may be related to environmental metal(loid)s contamination, along with other environmental factors. Further studies, implementing analysis of genetic polymorphisms, as well as investigation with long term follow-up, may yield to key aspects into the etiology of ALS. The interplay between different approaches (environmental, chemical, epidemiological, genetic) of our work provides new insights and methodology to the comprehension of the disease etiology.
\end{abstract}

\footnotetext{
* Corresponding author. Department of Earth and Environmental Sciences, University of Milano - Bicocca, Piazza della Scienza, 1, 20133, Milan, Italy.

** Corresponding author. Department of Biomedical, Surgical and Dental Sciences, University of Milan, Via C. Pascal, 36, 20133, Milan, Italy.

E-mail addresses: marina.tesauro@unimi.it (M. Tesauro); chiara.urani@unimib.it (C. Urani)

1 This work is dedicated to Maurizio Bruschi, our angel of Chemistry.

2 Integrated Models for Prevention and Protection in Environmental and Occupational Health, (MISTRAL) Interuniversity Research Center.
} 


\section{Introduction}

Amyotrophic Lateral Sclerosis (ALS) is a progressive neurodegenerative disorder of the motor system. It is the third most common neurodegenerative disease after Alzheimer's Disease and Parkinson's Disease and the most common form of adult-onset Motor Neuron Disease (Shang et al., 2015). ALS has a rapid progression and is uniformly fatal: death usually occurs following respiratory failure within 2-4 years from symptoms onset (Al-Chalabi and Hardiman, 2013).

ALS is a rare condition with an increased incidence in the last decades: currently the mean incidence rate is 2.8/100,000 in Europe and $1.8 / 100,000$ in North America, while the mean prevalence rate is 5.4/ 100,000 in Europe and 3.4/100,000 in North America. ALS incidence increases with age, with a peak in the seventh decade and it is likely that the overall incidence of ALS will increase as the world population ages (Chiò et al., 2013; Goutman and Feldman, 2020). The disease is slightly more common in men than in women, with an incidence of $1.5: 1$, and the incidence in men and women is about the same in familial ALS (Zarei et al., 2015). In North Italy during the 1995 to 2014 period, the mean annual incidence rate, adjusted for age and sex, in the 2001 Italian population was 2.78 per 100,000 population (95\% CI $2.57-2.96$ ) (men: 3.06 per 100,000; women: 2.51 per 100,000; rate ratio for men to women, 1.22:1) (Chiò et al., 2017).

The different increase of ALS incidence in men and women points to an effect of exogenous factors with a differential effect on the two sexes, acting on a genetic background. ALS is familial in only about $10 \%$ cases, with a family history, and sporadic (sALS) in the remaining 90\%, without apparent genetic link (Renton et al., 2014).

Advances in genetics have greatly contributed to the knowledge of ALS, with the discovery of Mendelian variants in at least 25 known genes that account for up to $70 \%$ of all cases of familial ALS and $10 \%$ of sporadic form. More specifically, mutations in four major genes namely, C9ORF72, SOD1, TARDBP, FUS account for $60 \%$ of familial cases and $10 \%$ of sporadic cases, while mutations in each of the remaining ALS genes have been identified in a small fraction of ALS patients (Brown and Al-Chalabi, 2017).

The observation of high frequencies of ALS in Guam, combined with a strong association with dietary habits of the indigenous population, supported the assumption of an environmental basis for ALS (Spencer et al., 2009; Al-Chalabi and Hardiman, 2013). In particular, in Guamanian patients Gellein et al. (2003) highlight that the plausible hypothesis regards imbalances in essential and toxic metals (e.g., Cd, Co, $\mathrm{Cu}, \mathrm{Fe}, \mathrm{Zn}$ ), with significantly elevated Cd concentrations in brain tissues in ALS patients. The incidence decline of ALS occurring with rapid changes in the epidemiology of the population, strongly suggests that environmental factors associated with former lifestyle of the population were involved. An interesting study (Román, 1996) reports a correlation between the presence of specific metals (e.g., Fe, Co, Zn) in environmental matrices and ALS in Guam island.

Indeed, current theories posit that the disease is a culmination of multiple genetic and environmental factors, with inevitable gene-environment interaction forming different steps along the pathway to the disease (Gellein et al., 2003; Al-Chalabi and Hardiman, 2013; Ingre et al., 2015; Wang et al., 2017; Chiò et al., 2018).

The role of environmental factors has been frequently reported in systematic reviews and meta-analysis of observational studies (see for example Yu et al., 2014; Oskarsson et al., 2015; Bozzoni et al., 2016; Wang et al., 2017; Riancho et al., 2018). Toxins from cyanobacteria, infectious agents, and mushrooms (Cox et al., 2016; Castanedo-Vazquez et al., 2019; French et al., 2019; Spencer et al., 2019; Fiore et al., 2020), hydrazine from fungal or industrial origin (Spencer, 2019; Spencer et al., 2019), cigarette smoking (Calvo et al., 2016), alcohol consumption (de Jong et al., 2012), physical work (Huisman et al., 2013), agonistic sport activities (Chiò et al., 2005; Gotkine et al., 2014; Visser et al., 2019), military service (Binazzi et al., 2009; Drouet et al., 2010; Beard and Kamel, 2015), head trauma (Filippini et al., 2020a; McKee et al., 2010; Seelen et al., 2014), exposure to electromagnetic fields (Hakansson et al., 2003; Gunnarsson and Bodin, 2018), pesticides (Chiò et al., 2009; Malek et al., 2012; Kamel et al., 2012; Vinceti et al., 2012; Vinceti et al., 2017), and Pb (Filippini et al., 2020b; Oh et al., 2007) are the environmental culprits most commonly cited for ALS (Zufiria et al., 2016), sometimes in controversial ways.

As far as in the early ' 80 s, case-control studies (Roelofs-Iverson et al., 1984) suggested an association between heavy metals, such as $\mathrm{Hg}$, $\mathrm{Pb}$, or other toxic metals and ALS.

Studies in the past two decades have highlighted possible roles of metals in the pathogenesis of ALS, and ionic homeostasis dysregulation has been proposed as the main trigger to motor-neuron degeneration (Kamel et al., 2002; Johnson and Atchinson, 2009; Sutedja et al., 2009; Sirabella et al., 2018). Higher concentrations of different essential and non-essential metals ( $\mathrm{Cu}, \mathrm{Zn}, \mathrm{Mn}, \mathrm{Al}, \mathrm{Cd}, \mathrm{Co}, \mathrm{Pb}, \mathrm{V}$ and $\mathrm{U}$ ) were found in cerebrospinal fluid and blood plasma from ALS patients, supporting the hypothesis of their involvement in the pathogenesis of ALS (Vinceti et al., 1997; Vinceti et al., 2017; Roos et al., 2013).

A cause-effect relationship between heavy cadmium exposure and ALS has also been suggested in nickel-cadmium battery workers. Noteworthy, Cd increases the permeability of the blood-brain barrier, and affects the activity of Cu-Zn superoxide dismutase and other enzymes involved in reactive oxygen species scavenging (Bar-Sela et al., 2001). Finally, as recently highlighted (Garza-Lombò et al., 2018), exposure to toxic metals (e.g., $\mathrm{Al}, \mathrm{As}, \mathrm{Cd}, \mathrm{Pb}$, and $\mathrm{Hg}$ ) is linked to several neurological disorders, including neurodegeneration.

In this work, we have collected environmental data from surface, ground and discharge water, and from soils of the province of Novara (Piedmont region, North Italy) and, particularly, of an industrial area, Briga area, located in the same province where metal contamination was mainly due to specific metallurgic activities. In this latter area of study, a previous epidemiologic work has shown evidence of a clear increase of mortality for ALS in the population (Uccelli et al., 2007). A recent study by our group (Tesauro et al., 2017) found incidence rates in the period 2002-2012 of 3.98, 5.14, and 2.97 cases/100,000 persons in Novara province, and 4.65, 4.27, and 4.98 in Briga area, for the total population, men and women, respectively. Stratifying for sex and age, incidence rates were higher in men in the 45-54 years age group and in women aged 65-74 years. Male to female ratio is 0.75 and 1.54, respectively in Briga area and in the rest of the province of Novara. A population-based case control study in the same area showed a positive association with ALS risk for occupational history, especially for exposure to solvents (OR $4.1195 \%$ CI 1.29-13.05), electromagnetic fields (OR 1.2 95\% CI 0.25-5.67), pesticides in particular fungicides (OR 2.97 95\% CI 0.24-36.75), and heavy metals such as $\mathrm{Pb}$ and $\mathrm{Hg}$ (OR 4.43 95\% CI 0.88-22.29 and OR 2.92 95\% CI 0.24-35.30, respectively) (Gagliardi, 2017). In particular, about metals, in the same area and in other provinces increased ALS risk for $\mathrm{Pb}$ (OR 3.66, 95\% CI 1.63-8.20), and for Cd (OR 1.79, 95\% CI 0.23-13.73) were found (Filippini et al., 2020a; Filippini et al., 2020b).

Due to the suggested relation between metals and ALS, this study aims at evaluating the possible role of environmental factors in the etiopathogenesis of ALS, with a particular focus on metal contamination. The specific features that prompted this study are the higher incidence of sALS in Briga area in comparison with the entire province, and the reported high levels of environmental contamination in the same area. Considering the significance of genetic mechanisms in ALS, a characterization for the main ALS genes has been performed to evaluate the genetic contribution for the ALS patients living in the area of study. 
In addition, the interference of toxic metals on the homeostasis of essential metals, and on the function of enzymes (e.g., SOD1) with relevant roles in neurodegeneration are herewith discussed.

\section{Material and methods}

\subsection{The area of study}

The study area (Fig. 1) is the province of Novara, located in Piedmont region (North Italy) with an extension of $1,340 \mathrm{~km}^{2}$. In particular, the Briga area here described includes 28 municipalities, defined with a radius of $10 \mathrm{Km}$ from the centroid Briga Novarese, and considered as an ALS cluster (Uccelli et al., 2007).

The population was almost of 370,000 people in 2019 with a density of 276 inhabitants $/ \mathrm{km}^{2}$. Generally, corn and rice represent the major cultivations in the South area, where manufacturing industries are also present along with one of the most important Italian oil refinery. In the Northern part of the province, and especially in the Briga area, there is a large number of metallurgic industries devoted to the production of valves and taps, which increased from 69 in 1961 to 300 in 1991, encompassing 110 and 3083 workers respectively. Around $22 \%$ of workers in that area were involved in tap production units, and in addition some family members of these workers were involved in 'home-work' (Rabellotti, 2003), such as the preparation of souls for mergers, mostly performed by women (Rogatti, 2013; Tesauro et al., 2017). In most recent years, in the three main municipalities of Briga area, Gozzano, Briga Novarese and Borgomanero, there were still $56\left(4.66 / \mathrm{km}^{2}\right), 20$ $\left(4.2 / \mathrm{km}^{2}\right)$ and $29\left(0.9 / \mathrm{km}^{2}\right)$ production units respectively in the metalworking sector (ARPA, 2010).

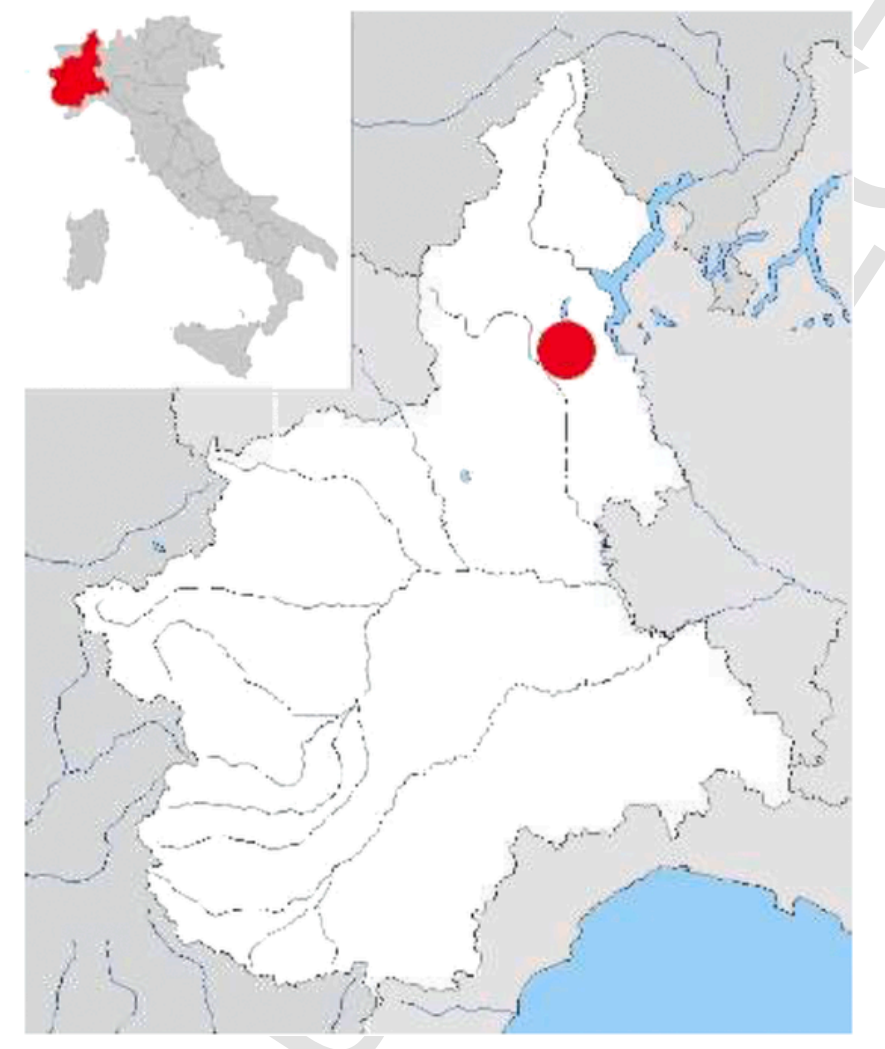

Fig. 1. Area of study: Briga area in the red circle (modified from d-maps.com). (For interpretation of the references to colour in this figure legend, the reader is referred to the Web version of this article.)

\subsection{Environmental data and processing}

The environmental data of the entire province of Novara were collected from the Regional Agency for the Protection of the Environment (Agenzia Regionale per la Protezione Ambientale - ARPA) of Piedmont and other sources (Cremonesi, 1996, study commissioned by Province of Novara). Environmental data collection covered the same years of the epidemiological analysis (2002-2012), followings years until 2018, and a previous period (1989-1995) in which an extensive monitoring campaign has been carried out in the Briga area.

Old chemical database is very fragmented, because of difficulties in obtaining paper-based data in old archives, not used for a long time, and inhomogeneities in chemical parameters analyzed. On the other hand, more recent digital data is easily accessible and homogeneous.

As for the analysis of soil in the Briga area, a campaign was carried out in the period May-April 2009 and analysis was carried out for the following metals and metalloids: As, total $\mathrm{Cr}, \mathrm{Cu}, \mathrm{Ni}, \mathrm{Pb}, \mathrm{Sn}$, and $\mathrm{Zn}$ (ARPA, 2010).

Data for surface and deep water, drinking water, and soil, were collected, processed, and compared with past (Legge 319/76) and current standards (D.Lgs 152/06). In addition, air quality data from the same ARPA database of Piedmont on areas not necessarily corresponding to the area of study were collected (data not shown).

\subsection{Genetic analyses}

The ALS patients of the previous epidemiological study (Tesauro et al., 2017), followed at the ALS tertiary clinical center at Novara Hospital (Italy), were enrolled for genetic analysis. According to medical history, all considered cases were classified as SALS. DNA was collected based on their availability at the time of the study.

The ALS cases have been screened for mutations in the 4 main ALS causative genes (SOD1, TARDBP, FUS, C9ORF72) and for ATXN2 CAG repeat locus whose intermediate alleles ( $>30$ CAG repeats) represent the main ALS susceptibility genetic factor in sALS. The genetic analysis was performed on two different groups: the group belonging to Briga area composed of 11 patients ( 7 men and 4 women with a mean age at onset of 62 years old, higher in women, 67 years old, and lower in men, 59 years old), and a second group used as a reference composed of 42 patients ( 28 men and 14 women, where the mean age at onset of the disease is of 65 years old, same for men and 63 for women), living in the territory of Novara province but outside the investigated area.

The study was approved by the local hospital ethics committee. A blood sample of the patients was drawn after informed consent to genetic analysis for research purposes.

Genomic DNA was isolated from peripheral blood lymphocytes using a standard protocol. The coding exons and 30bp of the flanking intron-exon boundaries of SOD1, TARDBP (exon 6), and FUS (exons 13, 14 and 15) have been PCR amplified, sequenced using the BigDye Terminator v3.1 sequencing kit (Applied Biosystems Inc.), and run on an ABI Prism 3100XL genetic analyzer. These exons were selected as the vast majority of known pathogenic variants are known to lie within these mutational hotspots. A repeat-primed PCR assay was used to screen for the presence of the GGGGCC hexanucleotide expansion in the first intron of C9ORF72 (DeJesus-Hernandez et al., 2011). The ATXN2 CAG repeat in exon 1 (Ref Seq NM_002973.3) was amplified using a fluorescent primer and sized by capillary electrophoresis on an ABI 3100XL genetic analyzer (Applied Biosystems, Foster City, CA). 


\section{Results}

\subsection{Chemical data reveal a heavy environmental contamination by metal(loid)s on different matrices}

The following paragraphs show all data on metal contamination in the considered matrices. All concentrations reported in the Tables are expressed as mean, median and maximum levels. The most relevant data to be considered is the maximum level, which better stresses the amount of environmental contamination close to the industrial discharge and in point-sources. In addition, the number of samples exceeding the law limits has to be taken into account.

Soil contamination. Metal concentrations in soil were compared to those measured for the Novara province (see Table 1). We found that the Briga area was characterized by a metal contamination, in particular for $\mathrm{Zn}, \mathrm{As}, \mathrm{Sn}, \mathrm{Pb}$ and $\mathrm{Cu}$, related to anthropic activities and discharges in soil. For $\mathrm{Zn}$ and As this was due to several sampling points with concentration values far above the law limits, whereas for Sn, to a spreader diffusion of the contamination with a large number of points with concentration higher than the background value determined for the Novara province. The concentrations of $\mathrm{Zn}$ and As were well correlated suggesting a common anthropic origin. Contamination of these two elements was on average higher in the eastern part of the Briga area with respect to the western border. $\mathrm{Cu}$ and $\mathrm{Pb}$ featured localized contamination with few points characterized by concentrations higher than the background value. Other metals $(\mathrm{Cr}, \mathrm{Ni}, \mathrm{Co}, \mathrm{V})$ did not show differences with respect to the value determined for the Novara province.

Surface water contamination. A high metal contamination in surface waters has been revealed by the monitoring campaign carried out in the period 1989-1995. This has been shown in particular for the Tancognino, La Grua and Agogna rivers.

Tancognino river in the period considered featured a dramatic metal contamination. Concentration values as high as $378 \mathrm{mg} / \mathrm{L}, 34 \mathrm{mg} / \mathrm{L}$, $68 \mathrm{mg} / \mathrm{L}, 125 \mathrm{mg} / \mathrm{L}$ and $247 \mathrm{mg} / \mathrm{L}$ have been measured for $\mathrm{Cr}(\mathrm{III})$, $\mathrm{Cr}(\mathrm{VI}), \mathrm{Cu}, \mathrm{Ni}$ and $\mathrm{Zn}$, respectively, associated with $\mathrm{pH}$ values as low as 2.3 (see Table 2). Even if several samples showed small metal contents with values lower than law limits, most of the samples highlighted very high concentrations for several metals, clearly suggest- ing frequent discharges of industrial wastes from metallurgic plants in the Tancognino river. It is important to note that the law limits considered for the comparison are those referred to the discharge of waste in surface waters, which are higher than the law limits for the metal concentration of the water body itself. The La Grua river was also highly contaminated by metals, even if only $\mathrm{Cu}$ was determined to be systematically higher than the limit law. Agogna river is the receptor of both Tancognino and La Grua rivers. The metals content was high also for this river, with sporadic exceeding of the law limit for $\mathrm{Cu}, \mathrm{Zn}, \mathrm{Al}$ and $\mathrm{Cr}$. The water quality of these rivers was considerably improved in the subsequent period, due to more strictly monitoring and control of industrial water discharges. Table 2 reports metal concentrations in the period 2012-2018, showing their decreased levels to values systematically lower than the limit law for all the metals considered.

Discharge in surface water, wastewater and soil. Results of the monitoring campaign carried out in the period 1989-1995 by collecting and analyzing samples at several point sources and discharging in the fresh surface waters of the Briga area also showed a severe metal contamination. Concentration values as high as $24.7,68,125$ and $378 \mathrm{mg} / \mathrm{L}$ have been measured for $\mathrm{Zn}, \mathrm{Cu}, \mathrm{Ni}$ and $\mathrm{Cr}(\mathrm{III})$, respectively, with several exceeding the law limit for all of the metal considered, with the exception of Mn (see Table 3). These emissions clearly explain the high level of metal contamination found in fresh surface waters due to point discharges from metallurgic activities. Discharges in wastewaters collected at several point sources in the same period give a picture similar to the one presented for discharge in surface water; very high content of $\mathrm{Zn}$, $\mathrm{Cu}, \mathrm{Ni}$ and $\mathrm{Cr}(\mathrm{III})$ were found, in many cases exceeding the standards. The monitoring campaign of water discharges in soil carried out in the period 1989-1995 also showed severe metal contamination, in particular for $\mathrm{Ni}$ and $\mathrm{Cu}$, as well as for Cd (see Table 3).

Groundwater contamination. In the period considered 2003-2008, the sampling at the piezometers, as well as at deep wells of the water supply systems, did not show exceeding in the law limits for metal concentrations (see Table 4). In particular, values measured in the period 2009-2018 in the Briga area do not reveal differences with respect to those reported for the Oleggio and Novara control areas. On the other hand, groundwater analysis from contaminated sites showed evidence of local metal contamination. In one contaminated site frequent exceeding the law limits for $\mathrm{Al}, \mathrm{Mn}$ and $\mathrm{Ni}$ were observed, with

Table 1

Descriptive statistics of concentrations of metal(loid)s ( $\mathrm{mg} / \mathrm{kg}$ ) in soil in Briga area, province of Novara and comparison with law limit and background value (BV).

\begin{tabular}{|c|c|c|c|c|c|c|c|c|}
\hline & $\mathrm{mg} / \mathrm{kg}$ & As & $\mathrm{Cr}$ & $\mathrm{Cu}$ & $\mathrm{Ni}$ & $\mathrm{Zn}$ & $\mathrm{Pb}$ & Sn \\
\hline & $\begin{array}{l}\text { Law } \\
\text { limits }^{a}\end{array}$ & 20 & 150 & 120 & 120 & 150 & 100 & 1 \\
\hline \multirow[t]{7}{*}{ Briga area $(3 * 3 \mathrm{~km})$} & BV & 14 & 150 & 51 & 130 & 105 & 55 & 4.3 \\
\hline & $\begin{array}{l}\text { n. } \\
\text { samples }\end{array}$ & 25 & 25 & 25 & 25 & 25 & 25 & 25 \\
\hline & Mean & 16.7 & 75.1 & 51.8 & 34.0 & 134.9 & 65.9 & 6.0 \\
\hline & Median & 9.8 & 64.0 & 40.0 & 31.0 & 100.0 & 51.0 & 5.4 \\
\hline & Max & 41.0 & 280.0 & 210.0 & 88.0 & 360.0 & 210.0 & 11.0 \\
\hline & $\begin{array}{l}\mathrm{n}>\text { law } \\
\text { limit }\end{array}$ & 8 & 1 & 1 & 0 & 8 & 3 & 25 \\
\hline & $\mathrm{n}>\mathrm{BV}$ & 9 & 1 & 7 & 0 & 11 & 10 & 20 \\
\hline \multirow[t]{6}{*}{ Novara province $(9 * 9 \mathrm{~km})$} & $\begin{array}{l}\text { n. } \\
\text { samples }\end{array}$ & 16 & 16 & 16 & 16 & 16 & 16 & 16 \\
\hline & Mean & 6.8 & 64.8 & 23.1 & 27.3 & 70.3 & 48.6 & 3.8 \\
\hline & Median & 7.5 & 56.5 & 24.5 & 27.0 & 58.0 & 34.5 & 3.7 \\
\hline & Max & 12.0 & 180.0 & 53.0 & 38.0 & 187.0 & 120.0 & 5.8 \\
\hline & $\begin{array}{l}\mathrm{n}>\text { law } \\
\text { limit }\end{array}$ & 0 & 1 & 0 & 0 & 1 & 2 & 16 \\
\hline & $\mathrm{n}>\mathrm{BV}$ & 0 & 1 & 1 & 0 & 1 & 5 & 3 \\
\hline
\end{tabular}

a Law limits according to Table 1 annex 5 D.Lgs 152/2006. 
Table 2

Metal(loid)s concentrations (in $\mu \mathrm{g} / \mathrm{L}$ ) in the surface waters (Tancognino, La Grua and Agogna rivers) determined in the various monitoring campaigns of the Briga area.

\begin{tabular}{|c|c|c|c|c|c|c|c|c|}
\hline Law limits ${ }^{a}$ & As & $\mathrm{Cd}$ & $\mathrm{Cr}(\mathrm{III}+\mathrm{VI})$ & $\mathrm{Ni}$ & $\mathrm{Cu}$ & $\mathrm{Zn}$ & $\mathrm{Mn}$ & $\mathrm{pH}$ \\
\hline & $\leq 500$ & $\leq 20$ & $\leq 2000$ & $\leq 2000$ & $\leq 100$ & $\leq 500$ & $\leq 2000$ & $5.5-9.5$ \\
\hline \multicolumn{9}{|l|}{$\begin{array}{l}\text { Tancognino river } \\
\text { 1989-1995 }\end{array}$} \\
\hline n. samples & 3 & 7 & 35 & 43 & 48 & 48 & 39 & 48 \\
\hline Mean & 4 & 13 & 14900 & 17700 & 3100 & 1420 & 96 & 6.2 \\
\hline Median & 5 & 5 & 860 & 5210 & 325 & 315 & 40 & 6.7 \\
\hline Max $\mu \mathrm{g} / \mathrm{L}$ (Min) & 5 & 4 & 378000 & 125000 & 68000 & 24700 & 1600 & $9.0(2.3)$ \\
\hline \multicolumn{9}{|l|}{$2000-2008$} \\
\hline n. samples & 1 & 20 & 40 & 20 & 20 & 20 & 20 & - \\
\hline Mean & $<3$ & $<0.5$ & 3.9 & 8.3 & 7.0 & 13.3 & 5.2 & - \\
\hline Median & $<3$ & $<0.5$ & 2.2 & 5.2 & 6.8 & 10 & 5 & - \\
\hline Max & $<3$ & $<0.5$ & 24 & 52 & 13 & 38 & 7.8 & - \\
\hline $\mathrm{n}>$ law limit & 0 & 0 & 0 & 0 & 0 & 0 & 0 & \\
\hline \multicolumn{9}{|l|}{ La Grua river } \\
\hline n. samples & - & - & 20 & 20 & 22 & 23 & 12 & 25 \\
\hline Mean & - & - & 91 & 280 & 180 & 120 & 24 & 7.1 \\
\hline Median & - & - & 45 & 180 & 85 & 90 & 20 & 6.9 \\
\hline Max & - & - & 670 & 800 & 1190 & 430 & 60 & 8.6 \\
\hline $\mathrm{n}>$ law limit & - & - & 0 & 0 & 10 & 0 & 0 & 0 \\
\hline \multicolumn{9}{|l|}{ 2012-2018 } \\
\hline n. samples & 12 & 31 & 39 & 31 & 31 & 31 & 31 & 61 \\
\hline Mean & $<3$ & 0.34 & 3.5 & 6.8 & 8.1 & 43.0 & 16.1 & 6.9 \\
\hline Median & $<3$ & $<0.5$ & 2.2 & 4.5 & 7 & $<10$ & 5 & 7 \\
\hline Max & $<3$ & $<0.5$ & 24 & 52 & 23.2 & 920 & 300 & 7 \\
\hline $\mathrm{n}>$ law limit & 0 & 0 & 0 & 0 & 0 & 0 & 0 & 0 \\
\hline \multicolumn{9}{|l|}{ Agogna river } \\
\hline \multicolumn{9}{|l|}{ 1989-1995 } \\
\hline n. samples & 6 & 0 & 19 & 22 & 19 & 27 & 15 & 28 \\
\hline Mean & 2.8 & - & 156 & 186 & 564 & 198 & 87 & 6.77 \\
\hline Median & 2.5 & - & 40 & 140 & 40 & 0.07 & 40 & 6.93 \\
\hline Max & 5 & - & 1240 & 680 & 4650 & 1480 & 360 & 8.68 \\
\hline $\mathrm{n}>$ law limit & 0 & - & 3 & 0 & 4 & 3 & 0 & 3 \\
\hline \multicolumn{9}{|l|}{ 2012-2018 } \\
\hline n. samples & 12 & 48 & 48 & 48 & 48 & 48 & 48 & 53 \\
\hline Mean & $<3$ & 0.40 & 2.1 & 1.9 & 5.0 & 34.9 & 7.7 & 7.03 \\
\hline Median & $<3$ & $<0.5$ & $<2$ & $<2$ & $<5$ & 37 & $<5$ & 7.05 \\
\hline Max & $<3$ & $<0.5$ & 3.9 & 3.6 & 7 & 67 & 44.7 & 7.7 \\
\hline $\mathrm{n}>$ law limit & 0 & 0 & 0 & 0 & 0 & 0 & 0 & 0 \\
\hline \multicolumn{9}{|l|}{ 2012-2018 Armeno - control } \\
\hline n. samples & 37 & 169 & 120 & 169 & 121 & 122 & 121 & 119 \\
\hline Mean & 3 & $<0.5$ & $<2$ & 2.2 & $<5$ & 81.2 & 7.9 & 6,9 \\
\hline Median & $<3$ & $<0.5$ & $<2$ & $<2$ & $<5$ & 89 & $<5$ & 7 \\
\hline Max & 3.2 & 0.7 & $<2$ & 10 & 8.9 & 137 & 116.8 & 7 \\
\hline $\mathrm{n}>$ law limit & 0 & 0 & 0 & 0 & 0 & 0 & 0 & 1 \\
\hline
\end{tabular}

a Law limits refer to the limit for the discharge in surface water according to Table 3 annex 5 D.Lgs. 152/2006.

values as high as 1260, 780 and $270 \mu \mathrm{g} / \mathrm{L}$, respectively. In a second contaminated site frequent exceeding in the law limits were determined for $\mathrm{Cr}$ and $\mathrm{Ni}$, whereas in a third contaminated site exceeding in the law limits were determined for $\mathrm{Ni}$ and $\mathrm{Mn}$. "Cascina Beatrice" was an extended wetland area of about $350,000 \mathrm{~m}^{2}$ in which flowed the Tancognino River. This site was classified as contaminated area in the Regional Registry of Contaminated Sites (see reference) due to a large metal contamination of soil and groundwater. Indeed, the monitoring campaign conducted in the period 2004-2008 using a network of 11 piezometers showed a severe metal contamination for $\mathrm{Al}, \mathrm{Ni}$, and $\mathrm{Mn}$, with values as high as $3190,203,1260 \mu \mathrm{g} / \mathrm{L}$, respectively, as well as a contamination above law limits for $\mathrm{Cu}$. The study conducted in the pe- riod 2003-2008 highlighted the presence of site-specific metal contamination ( $\mathrm{Al}, \mathrm{Mn}, \mathrm{Ni}, \mathrm{Cu}$ ) even if it was not demonstrated diffuse metal contamination of deep groundwater in the Briga area.

\subsection{Genetic analyses}

To test whether genetic mutations are clustered among the ALS patients belonging to the area of high ALS incidence (Briga area), we performed a mutational screening for the main ALS genes in the ALS patients belonging to the subset of ALS patients of Briga area and the rest of Novara province and referred to the tertiary ALS Centre in Novara. DNA samples were available for 11 out of 35 ALS patients belonging to 
Table 3

Metal(loid)s concentrations (in $\mu \mathrm{g} / \mathrm{L}$ ) of discharge in surface water, groundwater and soil determined in the various monitoring campaigns of the Briga area.

\begin{tabular}{|c|c|c|c|c|c|c|c|c|c|}
\hline \multicolumn{10}{|c|}{ Discharges in fresh surface waters in Briga area 1990-1995 } \\
\hline & As & Cd & Cr(III) & $\operatorname{Cr}(\mathrm{VI})$ & Ni & $\mathrm{Cu}$ & $\mathrm{Zn}$ & Mn & pH \\
\hline Law limits ${ }^{a}$ & $\leq 500$ & $\leq 20$ & $\leq 2000$ & $\leq 200$ & $\leq 2000$ & $\leq 100$ & $\leq 500$ & $\leq 2000$ & $5.5-9.5$ \\
\hline n. samples & 3 & 7 & 35 & 36 & 43 & 48 & 48 & 39 & 15 \\
\hline Mean & 4 & 10 & 14920 & 4450 & 17740 & 3130 & 1420 & 1000 & 6.22 \\
\hline Median & 5 & 5 & 860 & 3950 & 5210 & 325 & 315 & 40 & 6.70 \\
\hline Max (Min) & 5 & 40 & 378000 & 34200 & 125000 & 68000 & 24700 & 1600 & $9.01(2.25)$ \\
\hline $\mathrm{n}>$ law limit ( $\mathrm{n}<$ law limit $)$ & 0 & 1 & 16 & 20 & 27 & 29 & 18 & 0 & (9) \\
\hline \multicolumn{10}{|c|}{ Discharges in wastewaters in Briga area 1990-1995 } \\
\hline & As & Cd & Cr (III) & $\mathrm{Cr}(\mathrm{VI})$ & $\mathbf{N i}$ & $\mathrm{Cu}$ & $\mathrm{Zn}$ & Mn & pH \\
\hline Law limits ${ }^{a}$ & $\leq 500$ & $\leq 20$ & $\leq 4000$ & $\leq 200$ & $\leq 4000$ & $\leq 400$ & $\leq 1000$ & $\leq 4000$ & $5.5-9.5$ \\
\hline n. samples & - & - & 9 & 1 & 3 & 10 & 7 & 7 & 15 \\
\hline Mean & - & - & 1110 & 20 & 820 & 910 & 3230 & 130 & 7.10 \\
\hline Median & - & - & 70 & 6 & 110 & 120 & 150 & 90 & 6.8 \\
\hline Max (Min) & - & - & 5470 & 730 & 5220 & 18100 & 60000 & 760 & $12.5(5.01)$ \\
\hline $\mathrm{n}>$ law limit & - & - & 1 & 2 & 1 & 4 & 2 & 0 & 3 \\
\hline \multicolumn{10}{|c|}{ Discharges in soils in Briga area 1990-1995 } \\
\hline & As & Cd & \multirow{2}{*}{\multicolumn{2}{|c|}{$\begin{array}{l}\text { Cr (III) } \\
\leq 1000 \text { Cr(tot) }\end{array}$}} & $\mathrm{Cr}(\mathrm{VI})$ & $\mathrm{Ni}$ & $\mathrm{Cu}$ & Zn & Mn \\
\hline Law limits ${ }^{\mathrm{b}}$ & $\leq 50$ & n.p. ${ }^{c}$ & & & $\leq 200$ & $\leq 100$ & $\leq 500$ & $\leq 200$ & $6.0-8.0$ \\
\hline n. samples & 1 & 1 & 6 & 3 & 4 & 10 & 12 & 8 & 13 \\
\hline Mean & 1 & 1 & 120 & 180 & 410 & 96860 & 10030 & 420 & 8.47 \\
\hline Median & 20 & 70 & 70 & 10 & 120 & 170 & 120 & 220 & 8.79 \\
\hline Max (Min) & 20 & 70 & 300 & 510 & 1390 & 961000 & 112500 & 1900 & $12.00(5.81)$ \\
\hline $\mathrm{n}>$ law limit & 0 & 1 & 0 & 0 & 1 & 5 & 3 & 4 & 9 \\
\hline
\end{tabular}

a Law limits refer to the limit for the discharge in surface water and wastewater according to Tab 3 annex 5 D.Lgs. 152/2006.

b Law limits refer to the limit for the discharge in soil according to Tab 4 annex 5 D.Lgs. 152/2006.

c n. p. means not permitted.

Briga area, and for 42 out of 71 patients from the rest of Novara province, enrolled from the previous incidence study (Tesauro et al., 2017).

Regarding the Briga area, we found only one mutation in 1 patient, namely the GGGGCC pathological expansion in C9ORF72 gene, representing the most common mutation in sporadic and familial ALS cases in the Piedmont region (Chiò et al., 2012, 2020) as well as worldwide (Brown and Al-Chalabi, 2017). In the larger reference group of patients living outside the Briga area, 6 patients carried the GGGGCC pathological expansion in C9ORF72 gene, 1 patient carried a known missense mutation (p.L144F) in SOD1 and 3 patients carried intermediate alleles ( $>30$ CAG repeats) at ATXN2 CAG repeat locus.

Altogether, these data do not identify any genetic defect in the main ALS genes clustered in ALS patients belonging to the Briga area.

\section{Discussion}

Interactions between genes, lifestyle and environmental factors are proposed to contribute to ALS etiology (Ingre et al., 2015; Cicero et al., 2017; Wang et al., 2017; Castanedo-Vazquez et al., 2019; Swash and Eisen, 2020). In the present study, we took advantage of an area (Briga area) with a higher ALS incidence compared to Novara province (Italy), and the rest of Europe, to analyze the role of genetic factors and of metal(loid)s in ALS.

Case-control studies and meta-analyses report associations (positive or inverse) between increased risk of ALS and different metals (Roos et al., 2013; Bocca et al., 2015; Peters et al., 2016; Sheykhansari et al., 2018; Filippini et al., 2020b).

Based on recent and previous data on metal exposure and the possible risk to develop ALS, we have performed an analysis of chemical contamination of environmental matrices in a heavily polluted area of the Novara province (Briga area).

The main findings of this study are the demonstration that in the Briga area the most common metal contaminants are $\mathrm{Cu}, \mathrm{Zn}, \mathrm{Cr}, \mathrm{Ni}$ (widely used in tip-plating processes), that are highly present and above law limits in surface, discharge waters, and soil. In addition, other metals and metalloids, such as $\mathrm{Cd}, \mathrm{Pb}, \mathrm{Mn}$, and As, although not frequently assessed in monitoring campaigns, show a severe contamination in the same area.

Results of genetic analyses on available DNA samples show that ALS patients in the Briga area did not carry recurrent mutations or an excess of mutations in the major ALS related genes. Indeed, 1 out of 11 ALS patients carried the pathogenic hexanucleotide GGGGCC expansion on C9ORF72, the most common mutation in familial ALS (34.2\%), but also found in sporadic cases (5.9\%) worldwide (van Blitterswijk et al., 2012). Moreover, these data are consistent with frequency reported in a mutational analysis on a population-based ALS registry in the same region (Chiò et al., 2012).

We cannot exclude that mutations in other minor causative ALS genes are clustered in these patients and thus associated with the high ALS incidence in the Briga area. Nevertheless, the results showing no recurrent mutations on 10 out of 11 sALS are consistent with the hypothesis according to which environmental exposure may be implicated in the higher incidence of the disease in this area.

Different environmental matrices are connected to each other through powders, particulate matters (PM), dry deposition, evaporation processes, rain, snow, wind and other factors. In this way, pollutants can transfer in unpredictable concentrations and reach the humans through ingestion, inhalation or contact. This aspect has to be taken into account as possible synergic factor, particularly where heavy and diffused pollution occurs, as in the observed Briga area. The same transfer mechanism can apply to the metals highlighted as heavy contaminants in this study.

We collected data on air quality and PM but not strictly referred to the Briga area, and for this reason the data are not shown. Po Valley, where Briga area is located, is one of the most developed and industrialized area in Italy, characterized by a heavy air pollution. Negative health outcomes from outdoor pollution and particularly from PM exposure are well documented (Lucchini et al., 2012; Santurtun et 
Table 4

Metal(loid)s concentrations (in $\mu \mathrm{g} / \mathrm{L}$ ) of deep groundwater (drinking water) determined in the various monitoring campaigns of the Briga area.

\begin{tabular}{|c|c|c|c|c|c|c|c|}
\hline \multicolumn{8}{|c|}{ Deep Groundwater in Briga area 2003-2008 } \\
\hline & As & Cd & $\mathrm{Cr}(\mathrm{III}+\mathrm{VI})$ & $\mathbf{N i}$ & $\mathrm{Cu}$ & Zn & Mn \\
\hline \multicolumn{8}{|l|}{ limits ${ }^{a}$} \\
\hline n. samples & 19 & 19 & 19 & 19 & 19 & 1 & 19 \\
\hline Mean & $<0.8$ & $<0.12$ & 1.2 & 1.6 & 11.9 & $<50$ & 1.9 \\
\hline Median & $<0.8$ & $<0.12$ & $<1.2$ & 1 & $<5$ & $<50$ & $<1.2$ \\
\hline Max & $<0.8$ & $<0.12$ & 2 & 4 & 68 & $<50$ & 7 \\
\hline $\begin{array}{l}n>\text { law } \\
\text { limit }\end{array}$ & 0 & 0 & 0 & 0 & 0 & 0 & 0 \\
\hline \multicolumn{8}{|c|}{ Deep Groundwater in Briga area 2009-2018 } \\
\hline & As & Cd & $\mathrm{Cr}(\mathrm{III}+\mathrm{VI})$ & Ni & $\mathrm{Cu}$ & $\mathrm{Zn}$ & Mn \\
\hline \multicolumn{8}{|l|}{ limits ${ }^{a}$} \\
\hline n. samples & 16 & 68 & 80 & 79 & 79 & 79 & 80 \\
\hline Mean & $<3$ & $<0.5$ & 2.7 & 2.9 & 11.0 & 57.7 & 5.5 \\
\hline Median & $<3$ & $<0.5$ & $<2$ & $<2$ & $<5$ & $<50$ & $<5$ \\
\hline Max & $<3$ & $<0.5$ & $<5$ & 14.3 & 73 & 163 & 27 \\
\hline $\begin{array}{l}\mathrm{n}>\text { law } \\
\text { limit }\end{array}$ & 0 & 0 & 0 & 0 & 0 & 0 & 0 \\
\hline \multicolumn{8}{|c|}{ Deep Groundwater in Novara and Oleggio (control) areas 2009-2018 } \\
\hline & As & Cd & $\mathrm{Cr}(\mathrm{III}+\mathrm{VI})$ & Ni & $\mathrm{Cu}$ & $\mathrm{Zn}$ & Mn \\
\hline \multicolumn{8}{|l|}{ limits $^{a}$} \\
\hline n. samples & 6 & 28 & 34 & 34 & 28 & 34 & 34 \\
\hline Mean & $<3$ & $<0.5$ & 3.9 & 2.82 & $<5$ & $<50$ & 9.54 \\
\hline Median & $<3$ & $<0.5$ & 4.9 & $<2$ & $<5$ & $<50$ & $<5$ \\
\hline Max & $<3$ & $<0.5$ & 7.1 & 5 & $<5$ & $<50$ & 73 \\
\hline $\begin{array}{l}n>\text { law } \\
\text { limit }\end{array}$ & 0 & 0 & 0 & 0 & 0 & 0 & 2 \\
\hline
\end{tabular}

a Law limits refer to the limit for the groundwater according to Tab 2 annex 5 D.Lgs. 152/ 2006.

al., 2016), while studies on indoor PM are emerging. Only in recent years, it has been recognized that indoor concentrations of many pollutants, including particles, are the sum of outdoor contaminants and of those produced directly indoor (Smielowska et al., 2017).

An occupational exposure to metals is expected in tap production units, representing the main economic sources of the study area. Many different works describe the occupational risk factors, including metal exposure, and ALS (see among others, Bar-Sela et al., 2001; Capozzella et al., 2014; Gunnarsson and Bodin, 2018, 2019; Filippini et al., 2020b). The observed increased disease risk for women, and particularly for elderly women, is peculiar for the Briga area when compared to other studies. Women in past decades traditionally supported at their homes familial metallurgic activities in the process of tap manufacture (Rabellotti, 2003), thus being exposed to metals both through outdoor and indoor activities (i.e., supporting working activity and usual house works). Referred to indoor exposure, a recent study demonstrates that the concentrations of nanoparticles in indoor environments are greatly underestimated and related to domestic activities (Manigrasso et al., 2017). These particles can be translocated to the brain through olfactory bulb and play an important role in the etiopathogenesis of neurodegenerative diseases (i.e. Alzheimer's disease) (Manigrasso et al., 2019). In addition, translocation through circumventricular organs that lack a blood-brain barrier is possible (Kakaroubas et al., 2019).

As firstly described in Guam population for brain tissues (Gellein et al., 2003), toxic metals, such as Cd, are found in locus ceruleus (LC) neurons from human autopsies (Pamphlett et al., 2018), and in the olfactory bulbs of experimental animals exposed to Cd through diet or inhalation (Sunderman, 2001). The primary olfactory neurons repre- sent a likely way to transport $\mathrm{Cd}$ to their terminations in the olfactory bulb and into the brain (Arvidson, 1994). In the nervous system, $\mathrm{Cd}$ tends to accumulate in the choroids plexus at concentrations much greater than those found in the cerebrospinal fluid (CSF) and in other brain areas (Pamphlett and Kum Jew, 2013; Wang and Du, 2013, and references therein).

Due to their physiological functions (Sirabella et al., 2018), metal homeostasis is strictly regulated as their accumulation or deficiency leads to human diseases. In particular, ion dyshomeostasis and metal excess resulting in oxidative stress have been proposed as the main triggers of the cascade of events leading to motor neurons degeneration and loss. Defects in cellular $\mathrm{Ca}^{2+}$ signaling, and $\mathrm{Zn}^{2+}$ and $\mathrm{Cu}^{2+}$ homeostatic regulation are reported in ALS cases (Sirabella et al., 2018). Intracellular $\mathrm{Zn}$ concentration is strictly regulated by $\mathrm{Zn}$ importers, exporters, and binding proteins such as metallothioneins. Neuronal injury as a consequence of in vivo $\mathrm{Zn}$ mobilization and release occurs in several neurological disorders, including ALS (Bitanihirwe and Cunningham, 2009). In addition, $\mathrm{Zn}$ and $\mathrm{Cu}$ are metals with structural the first and catalytic functions the second in $\mathrm{Cu} / \mathrm{Zn}$-superoxide dismutase 1 (SOD1). This enzyme is mutated in around $20 \%$ of familial ALS cases, leading to a strong reactive oxygen species (ROS) generation. The increased ROS production, among which the superoxide anion, and the interaction with cell signaling pathways are possibly responsible of DNA damage and apoptosis of motor neurons. Thus, it is suggested that mutations do not cause ALS via loss of function, rather than through the alternate toxic gain of function (Hilton et al., 2015; Sirangelo and Iannuzzi, 2017).

Interestingly, Cd, among the metals present with a severe contamination in the study area of this work, is an inactive-redox heavy metal acting with mechanisms described as 'Trojan-horse' (Martelli et al., 2006). Cd is able to activate neuronal-specific and non specific mechanisms possibly involved in neurodegeneration in a neuronal human model (Forcella et al., 2020), and chronic exposure even to low level concentrations of $\mathrm{Cd}$ are able to induce dysregulation of essential metals such as $\mathrm{Cu}$ and $\mathrm{Zn}$ (Urani et al., 2015; Satarug et al., 2018).

Metal ion homeostasis is crucial for correct brain functions, and excess metal levels leading to metal dyshomeostasis have been proven to be a possible risk factor for neurodegenerative diseases including ALS, as demonstrated by chemical distribution of trace elements in post-mortem brain tissues (Gellein et al., 2003; Grochowski et al., 2019). In addition, to the causative role of metal dyshomeostasis in the process of oxidative damage, it is known the role of SOD1 mutation on Cu dysregulation in ALS, and the role of demetalled SOD1 in aggregates formation, typical hallmarks of ALS (Sirabella et al., 2018). These processes suggest a mutation-like effect of metal dysregulation in the formation of a non-functional SOD1 that could be one leading cause in oxidative stress generation of motor neurons.

Some limitations of this study should be noted, including the relatively small number of patients analyzed for genetic variants, and the absence of a thorough history of all possible environmental and other factors to which patients might be exposed. Only limited information was available, such as the exposure to solvents, some hobbies (photography, painting, hunting), occupation (welders, farmers, metallurgic workers), and some dietary habits. However, this information suggests important clues in relation to ALS etiology, such as photography and metallurgic occupation to be further taken into account.

\section{Conclusions}

This study supports the hypothesis that the previously described ALS cluster in Briga area may be related to environmental metal contamination, even supported by genetic analyses, although other environmental factors could have contributed to such disease excess.

Briga area is in fact one of the most important world tap manufacture district involving most people in that kind of activity, thus, being 
occupationally exposed to metals. This population during life span was exposed to indoor and outdoor environment, characterized by an elevated metal contamination.

An aspect to be implemented or included in future analyses regards the information about food exposition. The study design of the present work refers to previous epidemiological data collection not comprising specific information on metal dietary intake. Additionally, as observed in our chemical data collection in a very long period on the different matrices, the study area shows a substantial improvement of the environmental quality. As a consequence, it will be interesting to note whether a decreased ALS incidence rate will be observed, especially in the long term follow-up, also supported by further analyses able to identify genetic polymorphism. The outcomes of the new research may yield to key aspects into the etiology of ALS.

Despite the numerous studies carried out so far, the main risk factor(s) of this lethal neurodegenerative disease are still unknown. However, the interplay between different approaches and scientific visions (environmental, chemical, epidemiological, genetic, mechanistic) provides not only new insights to the comprehension of the disease, but also new hypothesis-driven approaches for stimulating future studies.

\section{Funding sources}

The authors acknowledge the M.I.U.R for partial funding (FFABR 2017 to CU). This study was partly funded by the AGING Project for Department of Excellence at the Department of Translational Medicine (DIMET), Università del Piemonte Orientale, Novara, Italy.

Approved by the local Ethic Committee of the Maggiore della Carità University Hospital (CE 54/05, 2005; CE 92/12, 2012).

\section{Credit authors statement}

Marina Tesauro: Conceptualization, Formal analysis, Investigation, Data collection and elaboration, Writing-original draft, writing-review \& editing; Maurizio Bruschi: Conceptualization, Formal analysis, Investigation, Data elaboration, Writing-original draft; Tommaso Filippini: Data elaboration and review; Sandra D'Alfonso: Data collection and elaboration, Writing-original draft, writing-review, Funding acquisition; Letizia Mazzini: Data collection, writing-review, Funding acquisition; Lucia Corrado: Data collection and elaboration, Funding acquisition; Michela Consonni: Data collection, writing-review; Marco Vinceti: Writing-review; Paola Fusi: Conceptualization, review; Urani Chiara: Conceptualization, Formal analysis, Investigation, Writing-original draft, writing-review \& editing, Funding acquisition.

\section{Uncited references}

; ; ; Decreto Legislativo 3 aprile, 2006; Gunnarsson et al., 1992; ; Swash and Eisen, 2020; Vinceti et al., 1997.

\section{Declaration of competing interest}

The authors declare that they have no known competing financial interests or personal relationships that could have appeared to influence the work reported in this paper.

\section{Acknowledgments}

The authors acknowledge ARPA Department of Novara (Italy) for providing environmental data analyzed in this work. The authors acknowledge the M.I.U.R for partial funding (NAZ-0387 2017 to CU). This study was partly funded by the AGING Project for Department of Excellence at the Department of Translational Medicine (DIMET), Università del Piemonte Orientale, Novara, Italy.
Al-Chalabi, A., Hardiman, O., 2013. The epidemiology of ALS: a conspiracy of genes, environment and time. Nat. Rev. Neurol. 9, 617-628. doi:10.1038/ nrneurol.2013.203.

ARPA Piemonte Dipartimento Provinciale di Novara, 2010. In: Approfondimento delle attività di analisi e di studio sulla contaminazione diffusa del suolo e delle acque sotterranee di alcune aree della Provincia di Novara, 155. http://www.arpa.piemonte. it.

ARPA Piemonte Rete di Monitoraggio per le Acque Sotterranee della Regione Piemontehttp://www.arpa.piemonte.it/approfondimenti/temi-ambientali/acqua/ rete-di-monitoraggio/rete-di-monitoraggio-delle-acque-sotterranee

ARPA Piemonte registry of contaminated sites of Piemonte regionhttps://www.regione piemonte.it/web/temi/ambiente-territorio/ambiente/amianto-bonifiche-terre-roccescavo/datipiemonteit-anagrafe-dei-siti-contaminati

Arvidson, B., 1994. A review of axonal transport of metals. Toxicology 88, 1-14. doi:10.1016/0300-483x(94)90107-4.

Bar-Sela, S., Reingold, S., Richter, E.D., 2001. Amyotrophic lateral sclerosis in a battery factory worker exposed to cadmium. Int. J. Occup. Environ. Health 7, 109-112. doi:10.1179/107735201800339470.

Beard, J.D., Kamel, F., 2015. Military service, deployments, and exposures in relation to amyotrophic lateral sclerosis etiology and survival. Epidemiol. Rev. 37, 55-70. doi:10.1093/epirev/mxu001.

Binazzi, A., Belli, S., Uccelli, R., Desiato, M.T., Talamanca, I.F., Antonini, G., Corsi, F.M., Scoppetta, C., Inghilleri, M., Pontieri, F.E., Vanacore, N., 2009. ALS Rome Group An exploratory case-control study on spinal and bulbar forms of amyotrophic lateral sclerosis in the province of Rome. Amyotroph. Lateral. Scler. 10, 361-369.

Bitanihirwe, B.K.Y., Cunningham, M.G., 2009. Zinc: the brain's dark horse. Synapse 63 , 1029-1049. doi:10.1002/syn.20683.

Bocca, B., Forte, G., Oggiano, R., Clemente, S., Asara, Y., Peruzzu, A., Farace, C., Pala, S., Fois, A.G., Pirina, P., Madeddu, R., 2015. Level of neurotoxic metals in amyotrophic lateral sclerosis: a population-based case-control study. J. Neurol. Sci. 359, 11-17. doi:10.1016/j.jns.2015.10.023.

Bozzoni, V, Pansarasa, O., Diamanti, L., Nosari, G., Cereda, C., Ceroni, M., 2016. Amyotrophic lateral sclerosis and environmental factors. Funct. Neurol. 31, 7-19. doi:10.11138/fneur/2016.31.1.007.

Brown, R.H., Al-Chalabi, A., 2017. Amyotrophic lateral sclerosis. N. Engl. J. Med. 377, 162-172. doi:10.1056/NEJMc1710379..

Calvo, A., Canosa, A., Bertuzzo, D., Cugnasco, P., Solero, L., Clerico, M., De Mercanti, M., Bersano, E., Cammarosano, S., Ilardi, A., Manera, U., Moglia, C., Marinou, K., Bottacchi, E., Pisano, F., Mora, G., Mazzini, L., Chiò, A., 2016. Influence of cigarette smoking on ALS outcome: a population-based study. J. Neurol. Neurosurg. Psychiatry 87, 1229-1233. doi:10.1136/jnnp-2016-313793.

Capozzella, A., Sacco, C., Chighine, A., Loreti, B., Scala, B., Casale, T., et al., 2014. Work related etiology of amyotrophic lateral sclerosis (ALS): a meta-analysis. Ann. Ig. 26, 456-472. doi:10.7416/ai.2014.2005.

Castanedo-Vazquez, D., Bosque-Varela, P., Sainz-Pelayo, A., Riancho, J., 2019. Infectous agents and amyotrophic lateral sclerosis: another piece of the puzzle of motor neuron degeneration. J. Neurol. 266, 27-36. doi:10.1007/s00415-018-8919-3.

Chiò, A., Benzi, G., Dossena, M., Mutani, R., Mora, G., 2005. Severely increased risk of amyotrophic lateral sclerosis among Italian professional football players. Brain 128, 472-476.

Chiò, A., Mora, G., Calvo, A., Mazzini, L., Bottacchi, E., Mutani, R., 2009. Epidemiology of ALS in Italy: a 10-year prospective population-based study. Neurology 72, 725-731. doi:10.1212/01.wnl.0000343008.26874.d1.

Chiò, A., Calvo, A., Mazzini, L., Cantello, R., Mora, G., Moglia, C., Corrado, L., D’Alfonso, S., Majounie, E., Renton, A., Pisano, F., Ossola, I., Brunetti, M., Traynor, B.J., Restagno, G., 2012. PARALS. Extensive genetics of ALS: a population-based study in Italy. Neurology 79, 1983-1989. doi:10.1212/WNL.0b013e3182735d36.

Chiò, A., Logroscino, G., Traynor, B.J., Collins, J., Simeone, J.C., Goldstein, L.A., White, L.A., 2013. Global epidemiology of amyotrophic lateral sclerosis: a systematic review of the published literature. Neuroepidemiology 41, 118-130.

Chiò, A., Mora, G., Moglia, C., Manera, U., Canosa, A., Cammarosano, S., Ilardi, A., Bertuzzo, D., Bersano, E., Cugnasco, P., Grassano, M., Pisano, F., Mazzini, L., Calvo, A., Piemonte and Valle d'Aosta Register for ALS (PARALS), 2017. Secular trends of amyotrophic lateral sclerosis: the Piemonte and valle d'Aosta register. JAMA Neurol 74 (9), 1097-1104. doi:10.1001/jamaneurol.2017.1387.

Chiò, A., Mazzini, L., D’Alfonso, S., Corrado, L., Canosa, A., Moglia, C., Manera, U., et al., 2018. The multistep hypothesis of ALS revisited. The role of genetic mutations. Neurology 91, e635-e642. doi:10.1212/WNL.0000000000005996.

Chiò, A., Moglia, C., Canosa, A., Manera, U., D’Ovidio, F., Vasta, R., Grassano, M., et al., 2020. ALS phenotype is influenced by age, sex, and genetics. A population-based study. Neurology 94 (8), e802-e810. doi:10.1212/WNL.0000000000008869.

Cicero, C.E., Mostile, G., Vasta, R., Rapisarda, V., Signorelli, S.S., Ferrante, M., Zappia, M., Nicoletti, 2017. Metals and neurodegenerative diseases. A systematic review. Environ. Res. 159, 82-94. doi:10.1016/j.envres.2017.07.048.

Cox, P.A., Davis, D.A., Mash, D.C., Metcalf, J.S., Banack, S.A., 2016. Dietary exposure to an environmental toxin triggers neurofibrillary tangles and amyloid deposits in the brain. Proc. Roy. Soc. B 283, 20152397. doi:10.1098/rspb.2015.2397.

Cremonesi, N., 1996. Definizione e studio degli impatti gravanti sul comprensorio del Basso Cusio. Relazione tecnica per la Provincia di Novara su Deliberazione della Giunta Provinciale 694- 19/06/1996.

Decreto Legislativo 3 aprile, 2006. n. 152 "Norme in materia ambientale" pubblicato nella Gazzetta Ufficiale n. 88 del 14 aprile 2006 - Supplemento Ordinario n. 96. 
DeJesus-Hernandez, M., Mackenzie, I.R., Boeve, B.F., Boxer, A.L., Baker, M., Rutherford, N.J., et al., 2011. Expanded GGGGCC hexanucleotide repeat in non-coding region of C9ORF72 causes chromosome 9p-linked frontotemporal dementia and amyotrophic lateral sclerosis. Neuron 72, 245-256. doi:10.1016/j.neuron.2011.09.011.

de Jong, S.W., Huisman, M.H., Sutedja, N.A., van der Kooi, A.J., de Visser, M., Schelhaas, H.J., Fischer, K., Veldink, J.H., van den Berg, L.H., 2012. Smoking, alcohol consumption, and the risk of amyotrophic lateral sclerosis: a population-based study. Am. J. Epidemiol. 176, 233-239. doi:10.1093/aje/kws015.

Drouet, A., Desjeux, G., Balaire, C., Thevenin-Garron, V., 2010. Retrospective study of ALS in French military personnel. Rev. Neurol. 166, 621-629. doi:10.1016/ j.neurol.2010.01.004.

Filippini, T., Fiore, M., Tesauro, M., Malagoli, C., Consonni, M., Violi, F., et al., 2020. Clinical and lifestyle factors and risk of amyotrophic lateral sclerosis: a population-based case-control study. Int. J. Environ. Res. Publ. Health 17, E857. doi:10.3390/ijerph17030857

Filippini, T., Tesauro, M., Fiore, M., Malagoli, C., Consonni, M., Violi, F., et al., 2020. Environmental and occupational risk factors of amyotrophic lateral sclerosis: a population-based case-control study. Int. J. Environ. Res. Publ. Health 17, E2882. doi:10.3390/ijerph17082882.

Fiore, M., Parisio, R., Filippini, T., Mantione, V., Platania, A., Odone, A., Signorelli, C., Pietrinig, V., Mandrioli, J., et al., 2020. Living near waterbodies as a proxy of cyanobacteria exposure and risk of amyotrophic lateral sclerosis: a population based case-control study. Environ. Res. 186, 109530. doi:10.1016/j.envres.2020.109530.

Forcella, M., Lau, P., Oldani, M., Melchioretto, P., Bogni, A., Gribaldo, L., Fusi, P., Urani, C., 2020. Neuronal specific and non-specific responses to cadmium possibly involved in neurodegeneration: a toxicogenomics study in a human neuronal cell model. Neurotoxicology 76, 162-173. doi:10.1016/j.neuro.2019.11.002.

French, P.W., Ludowyke, R.I., Guillemin, G.J., 2019. Fungal-contaminated grass and well water and sporadic amyotrophic lateral sclerosis. Neural Regen. Res. 14, 1490-1493. doi:10.4103/1673-5374.255959.

Gagliardi, I., 2017. [Fattori di rischio ambientale e sclerosi laterale amiotrofica: studio caso-controllo in Provincia di Novara] Master's degree thesis in Medicine and Surgery. University of Piemonte Orientale, Novara, Italy.

Garza-Lombò, C., Posadas, Y., Quintanar, L., Gonsebatt, M.E., Franco, R., 2018. Neurotoxicity linked to dysfunctional metal ion homeostasis and xenobiotic metal exposure: redox signaling and oxidative stress. Antioxidants Redox Signal. 28, 1669-1703. doi:10.1089/ars.2017.7272.

Gellein, K., Garruto, R.M., Syversen, T., Sjøbakk, T.E., Flaten, T.P., 2003. Concentrations of $\mathrm{Cd}, \mathrm{Co}, \mathrm{Cu}, \mathrm{Fe}, \mathrm{Mn}, \mathrm{Rb}, \mathrm{V}$, and $\mathrm{Zn}$ in formalin-fixed brain tissue in amyotrophic lateral sclerosis and parkinsonism-dementia complex of Guam determined by high-resolution ICP-MS. Biol. Trace Elem. Res. 96, 39-60. doi:10.1385/BTER:96:1-3:39.

Gotkine, M., Friedlander, Y., Hochner, H., 2014. Triathletes are over-represented in a population of patients with ALS. Amyotroph. Lateral Scler. Frontotemp. Degener. 15, 534-536. doi:10.3109/21678421.2014.932383.

Goutman, S.A., Feldman, E.L., 2020. Voicing the need for amyotrophic lateral sclerosis environmental research. JAMA Neurol 77, 543-544. doi:10.1001/ jamaneurol.2020.0051.

Grochowski, C., Blicharska, E., Krukow, P., Jonak, K., Maciejewski, M., Szczepanek, D., Jonak, K., Flieger, J., Maciejewski, R., 2019. Analysis of trace elements in human brain: its aim, methods, and concentration levels. Front. Chem. 7, 115. doi:10.3389/ fchem.2019.00115.

Gunnarsson, L.-G., Bodin, L., Soderfeldt, B., Axelson, O., 1992. A case-control study of motor neuron disease: its relation to heritability and occupational exposures, particularly to solvents. Br. J. Ind. Med. 49, 791-798.

Gunnarsson, L.-G., Bodin, L., 2018. Amyotrophic lateral sclerosis and occupational exposures: a systematic literature review and meta-analyses. Int. J. Environ. Res. Publ. Health 15, 2371. doi:10.3390/ijerph15112371.

Gunnarsson, L.-G., Bodin, L., 2019. Occupational exposures and neurodegenerative diseases - a systematic literature review and meta-analyses. Int. J. Environ. Res. Publ. Health 16, 337. doi:10.3390/ijerph16030337.

Hakansson, N., Gustavsson, P., Johansen, C., Floderus, B., 2003. Neurodegenerative diseases in welders and other workers exposed to high levels of magnetic fields. Epidemiology 14, 420-426. doi:10.1097/01.EDE.0000078446.76859.c9.

Hilton, J.B., White, A.R., Crouch, P.J., 2015. Metal-deficient SOD1 in amyotrophic lateral sclerosis. J. Mol. Med.. doi:10.1007/s00109-015-1273-3.

Huisman, M.H.B., Seelen, M., de Jong, S.W., et al., 2013. Lifetime physical activity and the risk of amyotrophic lateral sclerosis. J. Neurol. Neurosurg. Psychiatry 84, 976-981. doi:10.1136/jnnp-2012-304724.

Ingre, C., Roos, P.M., Piehl, F., Kamel, F., Fang, F., 2015. Risk factors for amyotrophic lateral sclerosis. Clin. Epidemiol. 7, 181-193. doi:10.2147/CLEP.S37505.

Johnson, F.O., Atchinson, W.D., 2009. The role of environmental mercury, lead and pesticide exposure in development of amyotrophic lateral sclerosis. Neurotoxicology 30, 761-765. doi:10.1016/j.neuro.2009.07.010.

Kakaroubas, N., Brennan, S., Keon, M., Saksena, N.K., 2019. Pathomechanisms of blood-brain barrier disruption in ALS. Neurosci. J 16 Article ID 2537698. doi:10.1155/2019/2537698

Kamel, F., Umbach, D.M., Munsat, T.L., Shefner, J.M., Hu, H., Sandler, D.P., 2002. Lead exposure and amyotrophic lateral sclerosis Epidemiology. 13, 311-319.

Kamel, F., Umbach, D.M., Bedlack, R.S., Richards, M., Watson, M., Alavanja, M.C.R., Blair, A., Hoppin, J.A., Schmidt, S., Sandler, D.P., 2012. Pesticide exposure and amyotrophic lateral sclerosis. Neurotoxicology 33, 457-462. doi:10.1016/j.neuro.2012.04.001.

Legge 10 maggio, 1976. n. 319 Norme per la tutela delle acque dall'inquinamento GU 29 maggio 1976 n. p. 141.
Lucchini, R.G., Dorman, D.C., Elder, A., Veronesi, B., 2012. Neurological impacts from inhalation of pollutants and the nose-brain connection. Neurotoxicology 33, 838-841. doi:10.1016/j.neuro.2011.12.001.

Malek, A.M., Barchowsky, A., Bowser, R., Youk, A., Talbott, E.O., 2012. Pesticide exposure as a risk factor for amyotrophic lateral sclerosis: a meta-analysis of epidemiological studies: pesticide exposure as a risk factor for ALS. Environ. Res. 117, 112-119. doi:10.1016/j.envres.2012.06.007.

Manigrasso, M., Vitali, M., Protano, C., Avino, P., 2017. Temporal evolution of ultrafine particles and of alveolar deposited surface area from main indoor combustion and noncombustion sources in a model room. Sci. Total Environ. 15, 1015-1026. doi:10.1016/j.scitotenv.2017.02.048.

Manigrasso, M., Protano, C., Astolfi, M.L., Massimi, L., Avino, P., Vitali, M., Canepari, S., 2019. Evidences of copper nanoparticle exposure in indoor environments: long term assessment, high-resolution field emission scanning electron microscopy evaluation, in silico respiratory dosimetry study and possible health implications. Sci. Total Environ. 653, 1192-1203. doi:10.1016/j.scitotenv.2018.11.044.

Martelli, A., Rousselet, E., Dycke, C., Bouron, A., Moulis, J.-M., 2006. Cadmium toxicity in animal cells by interference with essential metals. Biochimie 88, 1807-1814. doi:10.1016/j.biochi.2006.05.013.

McKee, A., Gavett, B.E., Stern, R.A., Nowinski, C.J., Cantu, R.C., Kowall, N.W., Perl, D.P., et al., 2010. TDP-43 proteinopathy and motor neuron disease in chronic traumatic encephalopathy. J. Neuropathol. Exp. Neurol. 69, 918-929. doi:10.1097/ NEN.0b013e3181ee7d85.

Oh, S.S., Kim, E., Lee, S.W., Kim, M.K., Kang, S.K., 2007. A case of amyotrophic lateral sclerosis in electronic parts manufacturing worker exposed to lead. Neurotoxicology 28, 324-327. doi:10.1016/j.neuro.2006.12.004.

Oskarsson, B., Horton, D.K., Mitsumoto, H., 2015. Potential environmental factors in amyotrophic lateral sclerosis. Neurol. Clin. 33, 877-888. doi:10.1016/ j.ncl.2015.07.009.

Pamphlett, R., Kum Jew, S., 2013. Uptake of inorganic mercury by human locus ceruleus and corticomotor neurons:implications for amyotrophic lateral sclerosis. Acta Neuropathol. Commun. 1, 13. doi:10.1186/2051-5960-1-13.

Pamphlett, R., Bishop, D.P., Jew, S.K., Doble, P.A., 2018. Age-related accumulation of toxic metals in the human locus ceruleus. PloS One 13, e0203627. doi:10.1371/ journal.pone.0203627.

Peters, T.L., Beard, D.J., Umbach, D.M., Allen, K., Keller, J., Mariosa, D., Sandler, D.P., et al., 2016. Blood levels of trace metals and amyotrophic lateral sclerosis. Neurotoxicology 54, 119-126.

Rabellotti, R., 2003. Il distretto della Rubinetteria del Piemonte Nord Orientale. In: Baici, E. (Ed.), L'economia novarese Analisi delle caratteristiche e prospettive del sistema economico provinciale. Interlinea, Novara.

Renton, A.E., Chiò, A., Traynor, B.J., 2014. State of play in amyotrophic lateral sclerosis. Nat. Neurosci. 17, 17-23. doi:10.1038/nn.3584.

Riancho, J., Bosque-Varela, P., Perez-Pereda, S., Povedano, M, de Munaín, A.L., Santurtun, A., 2018. The increasing importance of environmental conditions in amyotrophic lateral sclerosis. Int. J. Biometeorol. 62, 1361-1374. doi:10.1007/s00484-018-1550-2.

Roelofs-Iverson, R., Mulder, D.W., Elveback, L.R., Kurland, L.T., Molgaard, C., 1984. ALS and heavy metals: a pilot case-control study. Neurology 34, 393-395. doi:10.1212/ wnl.34.3.393.

Rogatti, C., 2013. Il distretto dei rubinetti: la strategia delle imprese del settore della rubinetteria. Il caso CARLO NOBILI S.p.A. Novara. Università degli Studi del Piemonte Orientale 'Amedeo Avogadro.

Román, G.C., 1996. Neuroepidemiology of amyotrophic lateral sclerosis: clues to aetiology and pathogenesis. J. Neurol. Neurosurg. Psychiatr. 61, 131-137. doi:10.1136/ jnnp.61.2.131.

Roos, P.M., Vesterberg, O., Syversen, T., Peder Flaten, T., Nordberg, M., 2013. Metal concentrations in cerebrospinal fluid and blood plasma from patients with amyotrophic lateral sclerosis. Biol. Trace Elem. Res. 151, 159-170. doi:10.1007/ s12011-012-9547-x.

Santurtun, A., Villar, A., Delgado-Alvarado, M., Riancho, J., 2016. Trends in motor neuron disease: association with latitude and air lead levels in Spain. Neurol. Sci. 37, 1271-1275.

Satarug, S., Nishijo, M., Ujjin, P., Moore, M.R., 2018. Chronic exposure to low-level cadmium induced zinc-copper dysregulation. J. Trace Elem. Med. Biol. 46, 32-38. doi:10.1016/j.jtemb.2017.11.008.

Seelen, M., van Doormaal, P.T., Visser, A.E., Huisman, M.H., Roozekrans, M.H., de Jong, S.W., et al., 2014. Prior medical conditions and the risk of amyotrophic lateral sclerosis. J. Neurol. 261, 1949-1956. doi:10.1007/s00415-014-7445-1.

Shang, H., Liu, G., Jiang, Y., Fu, J., Zhang, B., Song, R., Wang, W., 2015. Pathway analysis of two amyotrophic lateral sclerosis GWAS highlights shared genetic signals with Alzheimer's disease and Parkinson's disease. Mol. Neurobiol. 51, 361-369. doi:10.1007/s12035-014-8673-1.

Sheykhansari, S., Kozielski, K., Bill, J., Sitti, M., Gemmati, D., Zamboni, P., Singh, A.V., 2018. Redox metals homeostasis in multiple sclerosis and amyotrophic lateral sclerosis: a review. Cell Death Dis. 9, 348-363. doi:10.1038/s41419-018-0379-2.

Sirabella, R., Valsecchi, V., Anzilotti, S., Cuomo, O., Vinciguerra, A., Cepparulo, P., Brancaccio, P., Guida, N., Blondeau, N., Canzoniero, L.M.T., Franco, C., Amoroso, S., Annunziato, L., Pignataro, G., 2018. Ionic homeostasis maintenance in ALS: focus on new therapeutic targets. Front. Neurosci. 12, 510. doi:10.3389/fnins.2018.00510.

Sirangelo, I., Iannuzzi, C., 2017. The role of metal binding in the amyotrophic lateral sclerosis-related aggregation of copper-zinc superoxide dismutase. Molecules 22, 1429. doi:10.3390/molecules22091429. 
Smielowska, M., Marc, M., Zabiegala, B., 2017. Indoor air quality in public utility environments- a review. Environ. Sci. Pollut. Res. 24, 11166-11176. doi:10.1007/ s11356-017-8567-7.

Spencer, P.S., 2019. Hypothesis: etiologic and molecular mechanistic leads for sporadic neurodegenerative diseases based on experience with Western Pacific ALS/PDC. Front. Neurol. 10 article 754. doi:10.3389/fneur.2019.00754.

Spencer, P.S., Lagrange, E., Camu, W., 2019. ALS and environment: clues from spatial clustering? Rev. Neurol. 175, 652-663. doi:10.1016/j.neurol.2019.04.007.

Spencer, P.S., Palmer, V., Kisby, G., 2009. The ALS/PDC syndrome of Guam and the cycad hypothesis. Neurology 72, 473-474. doi:10.1212/01.wnl.0000344257.59693.cf.

Sunderman, F.W.J., 2001. Nasal toxicity, carcinogenicity, and olfactory uptake of metals. Ann. Clin. Lab. Sci. 31, 3-24.

Sutedja, N.A., Veldink, J.H., Fischer, K., Kromhout, H., Heederik, D., Huisman, M.H., Wokke, J.H., van den Berg, L.H., 2009. Exposure to chemicals and metals and risk of amyotrophic lateral sclerosis: a systematic review. Amyotroph. Lateral Scler. 10, 302-309. doi:10.3109/17482960802455416.

Swash, M., Eisen, A., 2020. Hypothesis: amyotrophic lateral sclerosis and environmental pollutants. Muscle Nerve 62, 187-191. doi:10.1002/mus.26855.

Tesauro, M., Consonni, M., Filippini, T., et al., 2017. Incidence of amyotrophic lateral sclerosis in the province of Novara, Italy, and possible role of environmental pollution. Amyotroph. Lateral Scler. Frontotemporal Degener. 18, 284-290. doi:10.1080/ 21678421.2017.1281961.

Uccelli, R., Binazzi, A., Altavista, P., Belli, S., Comba, P., Mastantonio, M., Vanacore, N., 2007. Geographic distribution of amyotrophic lateral sclerosis through motor neuron disease mortality data. Eur. J. Epidemiol. 22, 781-790. doi:10.1007/ s10654-007-9173-7.

Urani, C., Melchioretto, P., Bruschi, M., Fabbri, M., Sacco, M.G., Gribaldo, L., 2015. Impact of cadmium on intracellular zinc levels in HepG2 cells: quantitative evaluations and molecular effects. BioMed Res. Int. 1-11 article ID 949514. doi:10.1155/2015/ 949514.

van Blitterswijk, M., DeJesus-Hernandez, M., Rademakers, R., 2012. How do C9ORF72 repeat expansions cause ALS and FTD: can we learn from other non-coding repeat expansion disorders? Curr. Opin. Neurol. 25, 689-700. doi:10.1097/ WCO.0b013e32835a3efb.
Vinceti, M., Bottecchi, I., Fan, A., Finkelstein, Y., Mandrioli, J., 2012. Are environmental exposures to selenium, heavy metals, and pesticides risk factors for amyotrophic lateral sclerosis? Rev. Environ. Health 27, 19-41. doi:10.1515/reveh-2012-0002.

Vinceti, M., Filippini, T., Violi, F., Rothman, K.J., Costanzini, S., Malagoli, C., et al., 2017a. Pesticide exposure assessed through agricultural crop proximity and risk of amyotrophic lateral sclerosis. Environ. Health 16, 91. doi:10.1186/ s12940-017-0297-2.

Vinceti, M., Guidetti, D., Bergomi, M., Caselgrandi, E., Vivoli, R., Olmi, M., Rinaldi, L., Rovesti, S., Solime, F., 1997. Lead, cadmium, and selenium in the blood of patients with sporadic amyotrophic lateral sclerosis. Ital. J. Neurol. Sci. 18, 87-92. doi:10.1007/BF01999568.

Vinceti, M., Filippini, T., Mandrioli, J., Violi, F., Bargellini, A., Weuve, J., et al., 2017b. Lead, cadmium and mercury in cerebrospinal fluid and risk of amyotrophic lateral sclerosis: A case-control study. J. Trace Elem. Med. Biol. 43, 121-125. doi:10.1016/ j.jtemb.2016.12.012.

Visser, A.E., D’Ovidio, F., Peters, S., Vermeulen, R.C., Beghi, E., Chiò, A., Veldink, J.H., Logroscino, G., Hardiman, O., van den Berg, L.H., 2019. Euro-MOTOR consortium. Multicentre, population-based, case-control study of particulates, combustion products and amyotrophic lateral sclerosis risk. J. Neurol. Neurosurg. Psychiatry 90, 854-860. doi:10.1136/jnnp-2018-319779.

Wang, B., Du, Y., 2013. Cadmium and its neurotoxic effects. Oxid. Med. Cell. Longev. 12. doi:10.1155/2013/898034.

Wang, M.-D., Little, J., Gomes, J., Cashman, N.R., Krewski, D., 2017. Identification of risk factors associated with onset and progression of amyotrophic lateral sclerosis using systematic review and meta-analysis. Neurotoxicology 61, 101-130. doi:10.1016/ j.neuro.2016.06.015.

Zufiria, M., Gil-Bea, F.J., Fernandez-Torron, R., Poza, J.J., Munoz-Blanco, J.L., Rojas-Garcia, R., et al., 2016. ALS: a bucket of genes, environment, metabolism and unknown ingredients. Prog. Neurobiol. 142, 104-129. doi:10.1016/ j.pneurobio.2016.05.004.

Yu, Y., Su, F.C., Callaghan, B.C., Goutman, S.A., Batterman, S.A., Feldman, E.L., 2014 Environmental risk factors and amyotrophic lateral sclerosis (ALS): a case-control study of ALS in Michigan. PLoS One 9, e101186. doi:10.1371/journal.pone.0101186.

Zarei, S., Carr, K., Reiley, L., Diaz, K., Guerra, O., Altamirano, P.F., et al., 2015. A comprehensive review of amyotrophic lateral sclerosis. Surg. Neurol. Int. 6, 171. doi:10.4103/2152-7806.169561 